\title{
A GYÓGYPEDAGÓGIAI MOZGÁSFEJLESZTÉS SZEREPE ÉS MÓDSZERTANI ASPEKTUSAI
}

\author{
Szerzők: \\ Müller Anetta (Prof., PhD.) \\ Debreceni Egyetem (Magyarország) \\ Laoues-Czimbalmos Nóra \\ Debreceni Egyetem (Magyarország) \\ Szerdahelyi Zoltán \\ Debreceni Egyetem (Magyarország) \\ Boda Eszter \\ Eszterházy Károly Katolikus Egyetem \\ (Magyarország) \\ Mező Katalin (PhD.) \\ Debreceni Egyetem (Magyarország)
}

...és további két anonim lektor

Első szerző e-mail címe:

muller.anetta@econ.unideb.hu

Müller Anetta, Laoues-Czimbalmos Nóra, Szerdahelyi Zoltán, Boda Eszter, Mező Katalin (2021). A gyógypedagógiai mozgásfejlesztés szerepe és módszertani aspektusai. Különleges Bánásmód, 7. (3). 101-112. DOI $10.18458 /$ KB.2021.3.101

\begin{abstract}
Absztrakt
Az ember lételeme a mozgás. Igaz, hogy a különbözó életkori szakaszokban a mozgásszükséglet változik, de a mozgás, illetve annak fejlesztő szerepe és pozitív hatása egész életünket végigkíséri. A mozgásfejlesztés meghatározza az ép és sajátos nevelési igényú gyermekek képességeinek alakulását, mely nem csak a motoros, de a kognitív képességek javulásában egyaránt manifesztálódik. Tanulmányunkban a mozgásfejlődés és fejlesztés elméleti alapjait mutatjuk be szekunder irodalmak elemzésével. Kiemeljük és bemutatjuk a gyógypedagógiai területén alkalmazható mozgásfejlesztéssel kapcsolatos metodológiai sajátosságokat, melyek segíthetnek a speciális igényekkel rendelkező gyermekek képességbeli hátrányaik leküzdésében.
\end{abstract}

Kulcsszavak: sajátos nevelési igényú gyermek, mozgásfejlesztés, gyógypedagógia, módszertan Diszciplina: szociológia, pedagógia 


\section{Abstract \\ THE ROLE AND METHODOLOGICAL ASPECTS OF MOVEMENT DEVELOPMENT IN THE SPECLAL EDUCATION}

The essence of man is movement. It is true that the need for exercise varies at different age stages, but movement and its developmental role and positive impact accompany us throughout our lives. Movement development determines the development of the abilities of healthy and disabled children, which is manifested in the improvement of not only motor but also cognitive abilities. In our article, we present the theoretical foundations of movement development and development by analyzing secondary literature. We highlight and present the methodological features related to movement development that can be used in the field of special education, which can help children with special needs or disabilities to overcome their ability disadvantages.

Keywords: disabled child, movement development, special education

Disciplines: sociology, pedagogy

\section{Bevezetés}

Az ember egyik alapeleme a mozgás, az élet szükségszerű velejárója. Az ember mozgásos cselekvései - melyek cél általi meghatározottsággal bírnak, így tehát tudatosak - végig kísérik az életet a születéstől egészen a halálig. Az ember a filogenezis során az élővilág legfejlettebb egyedévé vált, melynek során a mozgásvariációk és mozgásrepertoár számtalan egyedi formája alakult ki (Piaget, 1976). Igaz ugyan, hogy az állatvilág egyes egyedei bizonyos mozgáshoz köthetô mutatókban jobb eredményt érnek el az embernél (pl. a mozgások sebessége), ugyanakkor az ember a mozgásvariációk és mozgásrepertoár sokféleségét tekintve az ember felülmúlja az állatok mozgását.

Az ember mozgásfejlődése kapcsán két kulcsfogalmat definiálhatunk, az egyik a növekedés, mely az emberi szervezetben bekövetkező mennyiségi változásokat eredményezi, a másik a fejlődés, mely minőségi változások sorozatát jelenti.

Farmosi (1999) a mozgásfejlődést, a mozgásformák és a mozgáskészségek egyéni fejlődéseként értelmezi. A mozgásformák fejlődésében a természetes mozgásokat, mint a kúszást, mászást, járást, futást, ugrást, dobást, elkapást, ütést és rúgást és az ízületi mozgékonyságot említi. A mozgáskészségek területén a kondicionális (a gyorsaság, az erő és az állóképesség) és a koordinációs (mozgásátállító, ritmus- és egyensúlyozó képességek, térbeli tájékozódó képesség, kinesztézia, stb.) képességeket emeli ki. A mozgásfejlődés során a természetes majd a művi mozgások gyakorlása által fejlődés tapasztalható a kondicionális képességekben, melyek a mozgások energetikai hátterét jelentik, illetve a mozgások ismételt gyakorlása és elsajátítása során a koordinációs képességek is fejlődnek, melyek a mozgások összehangolásáért, összerendezésért, illetve a pontos mozgás kivitelezésért felelnek.

Évszázados kutatási hagyományai vannak az emberi mozgásra irányuló megfigyeléseknek, amelyek központi témája azon mozgás- és motoros képességek fejlesztése, melyek az emberi ontogenetikai fejlődését több szempontból magyarázzák. A magyarázatok többféle fejlődéselméleti irányzata alakult ki: 1) a genetikai determinációt és biológiai érést hagsúlyozó elméletek; 2) a környezeti tanulást előtérbe helyező elméletek, 3) az öröklés és környezet egyenlőségét hangsúlyozó univerzális-konstruktivita elméletek; 4) a kulturális megközelítésű elméletek, valamint 5) a dinamikusrenszer elmélet szerinti felfogás:

- a genetikai determinációt és biológiai érést 
hangsúlyozó elméletek: a mozgásfejlődés vizsgálatával kapcsolatos tanulmányokban a kutatók egy része az öröklés és a genetika abszolút determináló jellegét hangsúlyozzák (Gesel, 1933). Ezek a vizsgálatok leginkább arra keresnek választ, hogy az öröklött genetikai állomány hogyan, illetve milyen mértékben determinálja az emberi mozgásrepertoárt, annak minőségi jegyeit és a mozgásos teljesítményt. Ezek a kutatások azok, amelyek az ember növekedésével és a fejlődés törvényszerűségeivel kapcsolatos felvetéseket helyezik fókuszba. Megvizsgálják a mozgás területén tapasztalható akceleráció-retardáció okait, illetve a motorikus fejlődést és teljesítményváltozást kiválttó tényezőket kutatják. A nativista kutatók szerint a különböző képességek, így a motorikus képességek, a vérmérsékleti tényezők, vagy az akarat is az elődeinktől öröklött tényezőktől függenek.

- a környezeti tanulást előtérbe helyező elméletek: a kutatók másik csoportja a behaviorista irányzat képviselői, akik az öröklés kizárólagossága helyett a környezeti tényezők mindenhatóságát vallják az emberi fejlődésben (első kutatói között pl. Locke, 1801).

Mindkét irányzatra igaz, hogy a fejlődésben kizárólag egy-egy tényező abszolút szerepét emelik, ki, mely meglehetősen szélsőséges felfogást tükröz.

- az öröklés és környezet egyenlőségét hangsúlyozó univerzális-konstruktivita elméletek: képviselői szerint az ember testi-leki és szociális fejlődésére az öröklés és a környezet együttesen hat, amivel a mozgásfejlődésben is kalkulálni kell. Az univerzális-konstruktivita felfogásban az öröklés és a környezet egyenlő és kölcsönös szerepét hangsúlyozták a fejlődésben (Piaget, 1976), s többnyire kiemelték, hogy a fejlődés szakaszai univerzálisak és kultúrától függetlenek.

- a kulturális megközelítésű elméletek: e nézet képviselői szerint a biológiai és a tapasztalati tényezők eltérők és eltérő hatással vannak a fejlődésre, az egyént aktuálisan körülvevő történelmi és kulturális közeg determinálja a fejlődést. A közvetlen környezeti, kulturális közegnek és tapasztalatoknak ebből kifolyólag jelentős szerepe van (Konzulin és mtsai, 2003).

- a dinamikusrendszer elmélet szerinti felfogás: Thelen és mtsai felfogásában (2001) az egész életen át tartó fejlődés nem más, mint az emberi testet felépítő biológiai, pszichológiai és szociokulturális változások és a környezeti hatások eredményeként kialakuló multistabil állapotok, viselkedési és cselekvési minták alakulásának sorozata, amely a születéstől a halál pillanatáig tart. Ez a bio-pszicho-szociokulturális felfogás erőteljesen érvényesül a fogyatékossággal élő személyek mozgásfejlődés felfogásában is.

$\mathrm{Az}$ épek és a fogyatékossággal élő személyek mozgásfejlődése és fejlesztése a kutatások örök témája, de, míg az épekkel foglalkozó hazai és nemzetközi kutatások széles skálája ismert, addig a fogyatékos személyek és speciális igényű gyerekekre irányuló kutatások nem képezek olyan teljességre törő rendszert (lásd pl. Ayres, 1995; MartonDévényi 2002, 2003; Oroszné, 2005). A mozgásfejlődés és fejlesztés kiemelt prioritással bír, hiszen a mozgásfejlődés az értelmi képességek fejlődését támogatja, segíti. A fogyatékossággal élő személyek vagy sajátos igényú gyerekek esetében a mozgásfejlődés azonban gyakran elmarad az elvárttól és/vagy időben megkésett és/vagy a mozgásminőségben, a teljesítményben is elmaradás tapasztalható, ami várhatóan kihat az értelmi fejlődésre is. Így a fogyatékossággal élő személyek vagy a speciális szükségletű gyerekek esetében a mozgásfejlesztés még inkább fontos (Livják és Szabó, 2017), hiszen a mozgásrepertoár bővítése, a mozgásmintázat, a koordinált mozgások kialakítása és a kondicionális képességek fejlesztése ebben az esetben nem csak a 
testi fejlődést segíti, de jelentős mértékben hozzájárul az értelmi képességek fejlesztéséhez is. Emellett a mozgás támogatja a tanulási képességeket, segíti a szocializációt a teljes személyiség fejlesztését is.

A mozgásfejlődéssel és fejlesztéssel már az ókorban is foglalkoztak (gondoljunk például a spártai nevelésre, vagy az ókori olimpiai játékokra), azonban a mozgáskoncepciók mint az emberi mozgásrepertoárt leírni képes rendszerelemek fogalmának meghatározásával és ezek leírásával, csak a 19. századtól kezdtek tudatosan foglalkozni (pl. Delsarte idézi Stebbins, 1886; Lábán, 1926). A 20. század közepétől pedig elindult az u.n. "movement education", azaz a mozgásnevelési irányzat beépítése a testneveléselméletbe és a módszertanokba, tantervekbe (Morison, 1956). Napjainkban az általános mozgásfejlesztés mellett a gyógypedagógiai mozgásfejlesztés iránt is egyre növekvő kereslet mutatkozik, melynek következtében megnövekedett az olyan jellegú kutatások száma is, melyek a mozgások terápiás jellegét hangsúlyozzák a korai fejlesztésben, a neveléstudományban vagy az egészségügyben (Márkus, 2017, 2019; Bartzokis et al. 2010; Maléth 2018; Pető, 2012).

A gyógypedagógiai mozgásfejlesztés két fő úton valósulhat meg: egyrészt hagyományos pedagógiai /gyógypedagógiai mozgásfejlesztés, mozgásedukáció keretében; másrészt speciális terápiák révén. A következőkben először a korai fejlesztésben hazánkban leggyakrabban alkalmazott mozgásterápiákat vesszük górcső alá Kelemen és társai (2015) összefoglaló tanulmánya alapján, majd részletezzük a gyógypedagógiai mozgásfejlesztés elméleti és gyakorlati hátterét.

\section{Mozgásterápiák}

A gyerekek fejlődésében a korai időszaknak igen fontos szerepe és jelentôsége van, mivel támogatja az idegrendszer fejlődését és érését, valamint a szociális kapcsolatok kialakulásában is meghatározó szerepe van. A kora gyermekkori intervenciót több kutató és szakember is kiemeli (ECI, ECEI program; Czeizel, 2009), hangsúlyozva, hogy ebben az időszakban (0-6 év), a legérzékenyebb időszakot kihasználva megfelelő, személyre szabott intervenciós eljárásokkal vagy akár különböző pedagógiai és terápiás módszerekkel lehet a leginkább a kisgyermekek fejlődési lehetőségeit segíteni, támogatni. Sokan leteszik a voksot amellé, hogy az eltérô fejlődésú gyermekek komplex fejlesztésének hatékonysága a minél korábbi életszakaszban kezdve jelent esélyt a motoros és értelmi fejlődésre. Czeizel $(2009,1$.) megfogalmazásában: „Korai intervencióban, fejlesztésben - a habilitáció részeként - részesülhetnek a 0-(5) 6 éves korú, értelmi-, érzékszervi-, mozgás- és halmozottan sérült, valamint viselkedészavarral küzdő gyermekek. A korai intervenciós, fejlesztő, programok célja a sérült, fogyatékos kisgyermekeket nevelő családok segítése, a gyermek sérült vagy lassabban kialakuló készségeinek fejlesztése, a jobb életminőség és a szociális kapcsolatok támogatása". Több szakirodalom is megerősíti a kora gyermekkori nevelés szerepét és jelentôségét, melyek a motoros tanulás mellett más területre is fókuszálnak (Guralnick, 2001; GortkaRákó, 2017, 2018; Mező F., 2017, Mező K., 2021).

A korai fejlesztések során gyakran élnek a mozgásterápiás programok biztosításával. A hazánkban leggyakrabban alkalmazott mozgásterápiák alapvető sajtásossága, hogy a terápiás mozgásfejlesztést csak az arra képzett, az adott speciális terápiában jártas személy (pl. gyógypedagógus, konduktor, gyógytestnevelő, mozgásterapeuta) végezheti. A mozgásterápiák nagy többsége már kora gyermekkorban elindul, így a terápiák alkalmazása összefonódik a korai fejlesztéssel. Bár nemzetközi szinten számos, fogyatékosság-specifikus terápia létezik, hazánkban a legelterjedtebb, leggyakrabban használt terápiák a Katona-féle neurorehabilitációs program, a Dévény terápia, a szenzoros-integrációs terápia, a Lakatosmódszer alapú terápia, az alapozó terápia valamint a bazális stimuláció, ezért a tanulmány terjedelmi 
keretei miatt, ezek rövid bemutatását végezzük el a következőkben (mindazok mellett, hogy tisztában vagyunk azzal, hogy számos egyéb terápia felszínre kerül hazánkban is):

1. Katona-féle neurorehabilitációs program: a fejlődésneurológia Magyarországon Dr. Katona Ferenc és munkacsoportja által kifejlesztett tudomány, mely az agy komplex fejlődésének ismeretében olyan módszert ad a gyakorló ideggyógyász kezébe, mellyel sikeresen felismerheti a kóros irányú idegrendszeri fejlődést. Erre épülóen dolgozták ki a neurohabilitációs tréninget a Svábhegyi Állami Gyermekgyógyintézet Fejlődésneurológiai Osztályán, mely diagnosztikus eljárás és terápiás módszer is egyben. A már újszülött korban elvégezhetô vizsgálat (video-EEG, agytörzsi és agykérgi kiváltott potenciál vizsgálat, a figyelem és emlékezet számítógépes vizsgálata, stb.) eredménye utalhat arra, hogy a gyermeknél kóros irányt vett a fejlődés. A „Katona-módszer” kidolgozásának alapjait jelentő publikációk, neurológiai kutatások eredményei napjainkban is népszerű szakirodalomnak számítanak a mozgásfejlesztés idegrendszeri kapcsolódásainak vonatkozásában. Katona (2007) szerint a humán központi idegrendszer fejlődése, annak változása illetve az érzékszervi és a mozfejlődés elválaszthatatlan egymástól, kölcsönösen hatnak egymásra és kiegészítik egymást. A mozgásfejlődés során az izomtónus kialakulása meghatározza a kinesztézia képességét. Az izomzat tónusa a beidegzés eredménye, amelyben az érzékelő receptorok visszajelző vagy „válasz” múködése befolyásolja a mozgató idegrostok működését. A vesztibuláris és vizuális rendszer együttmúködése már születésünktôl fogva befolyásolja és irányítja a mozgásunk fejlődését, így az érzékszervek (látás és hallás) egészséges fejlődése a mozgásfejlődést determinálja. (Katona, 2007; Lívják-Szabó, 2007; Kelemen és mtsai, 2015)

2. A Dévény módszer: Ezt a terápiás eljárást Dévény Anna gyógytornász, múvészi torna szakedző kettős képzettségéből fakadóan fejlesztette ki az 1970-es évek közepétől. Röviden DSGM-nek nevezik a Dévény Speciális Gimnasztika Módszer mozaikszavaként. Két területe van. A DSGM-I. mely speciális manuális technika segítségével a gyógyítást valósítja meg már születéstől kezdődően egyéni foglalkozásban. A DSGM-II. (speciális testképző gimnasztika), mely az I.-re épülően 3 éves kortól kiscsoportos formában a fejlesztést, korrekciót célozza meg. A Dévény módszer, egy olyan komplex terápia, mely az elemi mozgásmintákra és a mozgáskoordináció fejlesztésén alapszik, úgy hogy több agyi területre terjed ki az idegrendszer-fejlesztés. A Dévény Speciális manuális technika-Gimnasztika Módszer (DSGM) speciális manuális technikája (SMT) a képessé teszi a gyerekeket arra, hogy a mozgást végrehajtsák, míg más terápiás eljárások olyan mozgást kérnek amelynek végrehajtására egyedül nem képes (Dévény, 2007; Kelemen és mtsai, 2015).

3. Szenzoros integrációs terápia (SZIT) - Ayresterápia. Kifejlesztője Anna Jean Ayres amerikai gyermekpszichológus és agykutató. 1972-ben jelent meg könyve (Sensory Integration and Learning Disorders) „Szenzoros integráció és tanulási zavarok" címmel. Ebben a magatartási és tanulási zavaros gyermekek számára kifejlesztett szenzoros integrációs terápiát mutatja be. A terápia elméleti hátterét az adja, hogy ezeknél a gyermekeknél fennáll az érzékletek összerendezésének zavara, ami az idegrendszer éretlenségének következménye. Véleménye szerint az agy integratív funkciói fejleszthetők az egyensúlyi és más érzékszervi ingerek adásával, melyeket játékos, kreatív mozgás formájában ajánlanak fel a gyermek számára. A mozgásterápiák közül az Ayres-terápia egy szenzoros integrációs terápia, amely figyelembe veszi a gyermek fejlődését. Az Ayres-terápia két fó pillérre épül. Az egyik fő eleme az a neurológiai folyamat, mely feldolgozza és összerendezi a külső környezetből jövő ingereket (intermodalitás), hogy ezen információk tükrében a testünket célrairányítottan tudjuk mozgatni (önérzékelés vagy pro- 
priocepció). A másik eleme, a viselkedés és a neuropszichológiai folyamatok közötti kapcsolatra épül. A terápia kifejlesztője, Ayres ergoterapeuta szerint a szenzoros integrációs terápiára ott van szükség ahol ez az információfeldolgozás sérült (Lívják-Szabó, 2007; Kelemen és mtsai, 2015)

4. Lakatos-módszer: Lakatos Katalin konduktor, úszó-, szakedző. A szenzoros integrációt elősegítő mozgásterápia, a HRG, valamint a TSMT-I. és II. kidolgozója. A HRG (hidroterápiás rehabilitációs gimnasztika) egy 1994 óta levédett magyar fejlesztő módszer. A korai fejlesztés egyik leghatékonyabb módszere. A víz felhajtóereje következtében a testsúly csökken, a torna kisebb izomerőt igényel, így olyanok is el tudják végezni a gyakorlatokat, akik erre különben képtelenek. Leginkább csoportos mozgásfejlesztést, mozgásterápiát jelent. A Tervezett Szenzo-Motoros Tréningek egyéni (TSMT-I.) és csoportos (TSMT-II.) keretek között zajlanak. Az egyéni fejlesztés során a szülő a gyermeke trenírozásához probléma-specifikus, otthon végzendő feladatsort kap, amelyet szigorú szabályok betartásával (pl. feladatok sorrendje, ismétlésszáma, stb.) kell végrehajtaniuk (Lakatos, 2000; Kelemen és mtsai, 2015).

5. Alapozó terápia. Dr. Marton-Dévényi Éva ideg-, és elmeorvos, valamint munkatársai, Carl Henry Delacato philadelphiai neurológus és kutatócsoportja munkájának eredményeit alapul véve, dolgozták ki az alapozó terápiát. Ismereteik szerint a központi idegpályák kapcsolatában megjelenő diszfunkció az agy egyes részterületein, főként a mozgás-, a nyelvi, és a kognitív funkciók terén okozhat rendellenességet. Az első életév különösen szenzitív e tekintetben (Marton-Dévényi és mtsai, 1997; Kelemen és mtsai, 2015), ́́gy a korai fejlesztésnek van a legnagyobb jelentősége a felfogásukban.

6. Basális stimuláció. Németországban Andreas Fröhlich és Ursula Haupt 1975 és 82 között halmozottan sérült gyerekek számára dolgozta ki módszerét, a bazális stimulációt, mely a korai tanulás neurofiziológiai hatásaira épít. Ha a fejlődésben jelentősen akadályozott gyermekek számára könnyen érzékelhető, és érthetô ingereket biztosítunk, akkor ezek segítségével a gyermek megtanulja feldolgozni az ingereket, s ezzel együtt lehetőség nyilik a környezet felfogására. A "basális" jelző azt fejezi ki, hogy az önálló tapasztalatszerzést nélkülöző gyermek a terápia folyamán sokoldalú érzékelési információk felvételére válik képessé, s ez fogja „megalapozni” a környezet adekvát felfogását. Mindez hétköznapi és részben speciális eszközrendszer segítségével érhető el. A "stimuláció" (ingerlés) az alapvető érzékelési modalitások intenzív múködtetését jelenti a terapeuta szakszerú irányításával (idézi Kelemen és mtsai, 2015).

\section{A mozgásfejlesztés elméleti alapjai}

A mozgásfejlesztés nem csak terápiás keretek között valósulhat meg, hanem a hagyományos óvodai, iskolai nevelés, a mozgásedukáció keretébe ágyazottan is. A szakirodalmak felhívják a figyelmet a mozgásfejlődés és tanulás közti azonosságokra és különbségre. A mozgásfejlődés - mely alatt a mozgásmintázatnak és a motoros képességeknek a fejlődését értjük, amely legtöbbször az életkorok vonatkozásában kap figyelmet - a legtöbb esetben kiegészül a motoros tanulással (Rosengren et. al. 2003). A tanulás során ugyanis, ahogy a gyerek ismétli az adott természetes mozgást úgy egyre inkább javulni fog a mozgáskoordináció, mely által a mozgás technikai kivitelezése, ,jósága” is fejlódik. A különböző természetes és művi mozgások gyakorlása során nem csak a mozgásminta vésődik be és szilárdul meg automatizált mozgássá, azaz dinamikus sztereotípiává, hanem javulnak a motoros képességbeli mutatók is. Amikor a gyermek a kúszást, mászást, lépcsőn fel-és le járást ismétli és gyakorolja úgy javul a kar és vállöv izomzatának vagy akár a láb izomzatának ereje is.

Több szerző felveti az alábbi kérdéseket: a gyerekek tanulás útján sajátítják el a kúszást vagy a 
járást vagy ezek az u.n. lokomotorikus képességeik fejlődnek? A gyerekek „megtanulják” az íróeszközök fogását avagy fejlödik a markolási készégük? A dobási vagy markolási képességeket megtanulják avagy a fejlődés során alakul ki? (Roberton 1984)

A fejlődés folyamtában filogenetikai és ontogenetikai változások sorozata zajlik. Amíg a filogenetikai változás a faj minden tagjában bekövetkező változásnak tekinthetô, ezért ezt fejlődési változásnak is nevezhetjük, addig az ontogenetikus változások, az egyéni jellemző sajátosságokkal bírnak, amit tanulás jelentős mértékben befolyásol. A járás, az ülés a fejlódés során alakul (igaz életünk során gyakoroljuk), s bár vannak egyéni különbségek ezekben a mozgásokban mégis nehezen értelmezhetô a járás vagy az ülés „kiváló” szintje. A motoros viselkedés egyéb formái, mint pl. a zsonglőrködés, a rajzolás, egyértelmú magas teljesítményszintet mutatnak, azok egyértelmúen a tanulás, nem pedig a fejlődés eredményeként nevesíthetőek (Rosengren et. al. 2003). McGraw is felveti több munkájában $(1935 / 75,1943)$ az öröklés és a környezet hatásának szerepét. McGraw (idézi Völgyesi, 1993) egypetéjü ikreken végzett kísérlete során arra kereste a választ, hogy a járás (mely természetes mozgásunk) tanulását meggyorsítja-e, ha gyakorolja a gyermek ezt a mozgásformát. Kutatásában az ikerpár egyik tagjával rendszeresen és tudatosan gyakoroltatta a természetes mozgások közül a mászást, az ülést, a járást valamint a lépcsőn fel- és lefelé való járást is. Az ikerpár másik tagja pedig nem végzett felnőtt irányítása alatti tudatos gyakorlást ezekben a mozgásformákban. Bizonyos idő elteltével összevetette a két gyermek mozgásos tevékenységeit és azt állapította meg, hogy az alapvető tevékenységekben (mászás, ülés, járás) nem tapasztalható semmilyen különbség a mozgásmintázatban, illetve annak technikai jóságában. Azonban, különbséget tudott igazolni a speciális mozgásos aktivitás terén, speciális ügyességet követelő mozgások esetében. Azt vette észre, hogy domináns előnyre tett szert az a gyermek, akivel, mint különleges (ügyességet fejlesztô) mozgást gyakoroltatták a lépcsőn fel és lefelé való járást. Így tehát ez a kísérlet megerősít bennünket abban, hogy az örökletes tényezők határozzák meg leginkább az ember alapvető mozgásfunkcióit és annak fejlődését, de azoknál a mozgásos feladatoknál, melyek igénylik az ügyességet, készséget a tanulásnak azon belül is a gyakorlásnak (környezetnek) domináns szerepe van. Ezt a tényt állapítja meg Ozsváth (1990, idézi Müller, 2004) is, csak idősebb gyerekek mintáján megvalósult kísérlete kapcsán. Ozsváth egy három éves fejlesztő program után azt a megállapítást tette, hogy az alsó tagozatos gyermekek képesek nagyon bonyolult koordinációs feladatokat is megoldani (ezek a gyakorlatok a tantervi előírásokon is túl mutatnak) így a koordinációs képességek fejlesztésében a szakszerû irányított gyakorlásnak domináns szerepe van. Azt tapasztalta, hogy a három éves fejlesztő munka befejeztével (amely tartalmazta a különböző koordinációs képességek fejlesztését pl. a térérzékelés, egyensúlyérzék, izomérzékelés, az iram és idóérzékelés, tempó- és ritmusérzék, a távolságbecslés, futó, ugró, dobó, elkapó, rúgó, cselezô, védekező képesség és kéz- és lábügyesség stb.) azok a tanulók, akik részt vettek a fejlesztésben eredményesebbnek bizonyultak azon társaiknál, akik nem részesültek ebben a fejlesztô programban. Így azt állapíthatjuk meg, hogy a mozgások pontosságát, az eredményességet a koordináció színvonalát nagymértékben befolyásolja a „kellő” időben megvalósuló irányított gyakorlás. A múvi mozgásaink is a motoros tanulás eredményei. A motoros tanulás során gyakran merül fel bennünk az a kérdés, hogy mikor tekinthető a mozgástanulás folyamata befejezettnek vagy befejezettnek tekinthető-e egyáltalán? Elég ha egyszer produkálta az elsajátítandó mozgásformát vagy a többszöri ismétlés az a teljesítmény-konstancia vagyis a többszöri reprodukció jelenti nekünk a mozgástanulás eredményességét.

A mozgástanulás során több szerző felhívja a figyelmet a teljesítményálladóság a mozgások rep- 
rodukálásának képességére, hiszen a többször végrehajtott mozgásminta a mozgások bevésődésének és megszilárdulásának egyik feltétele. Több szerző (Nádori-Büchler, 1979, Király-Szakály, 2011) a mozgástanulás durva, finom koordinációs szakaszát különbözteti meg, amely elvezethet az automatizált, berögzött mozgás meglétéhez és egy olyan motoros vagy mozgáskészség kialakulásához, mely lehetôvé teszi az adott mozgásforma akár változó körülmények közti alkalmazását is.

\section{A gyógypedagógiai mozgásfejlesztés alap- elvei és módszertani aspektusai}

A mozgások elsajátíttatása kapcsán a gyermekek mozgásfejlesztésében fontos bizonyos alapelveket és módszertani sajátosságokat figyelembe venni, melyek a gyógypedagógia területén bizonyos specialitásokat is magukban hordoznak, s a gyermekek sajátos nevelési igényéhez igazodnak.

A gyógypedagógiai mozgásfejlesztésben is alkalmazhatjuk a Comeniusi didaktika alapelveit (Comenius Didactica Magna, eredeti kiadás 1657):

A szemléletesség elve, mely a mozgásoktatásban különös jelentőséggel bír. A mozgásoktatásban a verbális és vizuális ismeretközlés közül a vizuális sokkal eredményesebb, azaz ha bemutatjuk vagy bemutattatjuk a mozgást sokkal hamarabb elsajátítja a gyermek, mint ha elmondjuk vagy szóban ismertetjük azt. Azonban a magyarázat és bemutatás együttese ennél is hatásosabb. A gyógypedagógiai mozgásfejlesztés során sok esetben az értelmi képességek korlátozottsága miatt, vagy egyéb probléma (például hallássérülés) következtében szinte csupán a bemutatásra, szemléltetésre hagyatkozhatunk. A helyes bemutatás orientálja és motiválja a gyerekeket a feladatra, valamint segíti a mozgásos feladat mozgásképének megismerésében. Van azonban kivétel is, hiszen a gyengénlátók vagy vakok mozgásoktatásában a vizualitás korlátozottsága miatt ez nem valósítható meg, természetesen ebben az esetben a többi érzékszervre kell hagyatkozni, így például a verbalitás és a hang alapú instrukció alkalmazható. A mozgásfejlesztésben különösen fontos a szemléletes bemutatás, bemutattatás vagy vizuális szemléltetés. Ép tanulók esetében is azt tapasztalták, hogy a bemutatás sokkal hatékonyabb, mint a szóban közlés módszere.

A tudatosság elve. Comenius a tudatosság elvét szorosan hozzákapcsolta a szemléletesség alapelvéhez (idézi Geréb, 1958), mivel a két alapelv, együttesen határozza meg a tudásanyag elsajátításának sikerességét. A mozgástanitás során a tudatosság jelenti azt is, hogy a mozgástanítás vagy mozgásfejlesztés közösen definiálható. Ez azt jelenti, hogy nem elegendő megtanítani a testgyakorlatokat. A különbözô mozgásokat nem csak elsajátítani, hanem folyamatosan tudatosítani kell, annak érdekében, hogy a résztvevő megértse, hogy mit miért csinál. A mozgás technikájának elsajátítás differenciációs folyamata a „meg nem erősített mozgások gátlásán”, illetve a „mozgás analizátor megerősített feltételes kapcsolatainak a megszilárdításán" alapszik (Gyapay, 1963). Így a mozgástanulás során a hibáknak/ vagy a helyes mozdulatoknak szavakban történő jelölése megerősítő vagy gátló ingerként hat, amely a feltétlen (közvetlen) ingert helyettesíti. A gyógypedagógiai mozgásfejlesztés során a hibajavítás azonban nem minden esetben tud szóbeli instrukcióval megvalósulni, e helyett pl. kényszerítő helyzetek alkalmazása, vagy a helyes mozdulat kialakítása is eredményre vezethet. Egyszerú példa: a kúszás során abban az esetben, ha a gyerek nem tenyérrel, hanem behajlított ujjakkal akar kúszni, valószínúleg sikertelen lesz a kivitelezés. Ilyen esetben kényszerítő helyzet lehet, ha a hasánál megfogjuk a gyermeket és a talaj felé közelítjük kézzel, melynek hatására neki tenyérrel kell letámaszkodnia, de ha ekkor is behajlítja az ujjait, akkor megfogjuk és kinyúitjuk, azaz mozgatással javítjuk a hibát. Ugyanez érhető el, ha fit-ball vagy gimnasztika labdára helyezzük a gyereket hassal. A labda nagy, ezért a gyermeknek a tenyerét kell, hogy rátegye a labdára, amikor a labdát a gyerekkel 
együtt előrefelé mozgatjuk. Hibajavitásként itt is a kezünkkel megfogjuk a gyermek ujjait és kinyújtjuk, ha nem sikerül neki egyedül a kényszerítő helyzet által.

A tudatosság elve azt is jelenti, hogy a tanulás során az elsajátított mozgást a gyermekkel változatos körülmények között, változó feltételek mellett gyakoroltatjuk. A gyógypedagógiai mozgásfejlesztés során az elsajátított mozgásokat - például járás, kúszás, mászás - alkalmazásának gyakortatását gyakran különböző akadálypálya kialakításával gyakoroltatjuk, melyek során a gyerekeknek változó körülményekhez igazodva kell a mozgást célszerúen végrehajtani. Másik jó lehetőség a labdajátékok alkalmazása, melyek során képessé válnak a szabályok figyelembe vételével a labdabirtoklást, továbbjátszást megvalósítani, ahol a folyamatosan változó környezet maga a labda, hiszen a feléje guruló vagy érkező labda sebessége iránya nem konstans.

A fokozatosság (a tananyag koncentrikus bövïlésének elve) és rendszeresség elve. A fokozatosság, az ismeretek, képességek koncentrikus bővülését jelenti. Comenius hangsúlyozta, hogy a tanítás során a következő alapszabályok mentén szükséges haladni:

1. az egyszerútől az összetett,

2. a konkréttól az elvont,

3. a tényektôl a következtetések,

4. a könnyútőll a nehéz,

5. a közelitől a távoli felé.

A mozgások elsajátítása kapcsán is az alapszabályokat betartva sajátíttatjuk el a mozgásokat. Például először a gurulóátfordulást előre tanítjuk, majd utána a hátrafelé végzett formát, hiszen a hátrafelé történő gurulás azt is jelenti, hogy a végrehajtó személy, vagy gyerek a haladás irányát tekintve „vak”, vagyis vizuális kontroll nélkül, annak korlátozásával hajtja végre a feladatot, ami nehezebb feladatot jelent. A foglalkozások során is először az egyszerúbb gimnasztikai elemektól haladhatunk a bonyolultabb vagyis összetett elemek felé, utána elemkapcsolatokat vagy akár gyakor- latláncot is építhetünk a mozgásból. A rendszereség elvét alkalmazva, fontos, hogy a tanítási anyag szerkezeti felépítése logikus legyen, s hogy átadása során „az előzmény készítse elő az utána következók útját". Az ismereteknek, az elsajátítandó képességeknek ebből következően szervesen egymásra kell épülniük. A mozgásfejlesztésben is igen fontos a rendszeresség, hiszen a kondicionális képességek csak akkor fejlődnek, ha a külső terhelés bizonyos, rendszeres időközönként ismétlődnek. A mozgásvégrehajtás minőségében bekövetkező pozitív változást is csak a céltudatos, rendszeres irányított gyakorlás javítja (Osváth 1990).

A következetesség elve. A gyermek életkorát mindig figyelmebe kell venni, amikor megszabjuk a mozgásfejlesztés anyagát, mind a fejlesztés mélységében, mind a részletességében. Az életkori sajátosságokon tól az értelmi képességeket és az értlemi feljettség fokát is célszerú szem előtt tartani a gyógypedagógiai mozgásfejlesztés során. Kerülni kell a köevtkezetlenséget és a kapkodást a mozgások tanítása során.

A „coméniusi elveket” a gyógypedagógiai mozgásfejlesztésben az az alábbiakkal egészíthetjük ki:

- a teljesítőképesség elve,

- a szilárdság elve,

- személyre szabottság, a speciális igények figyelembe vételének elve,

- motiváció elve,

- aktivitás elve,

- közös munka és az egyéni bánásmód elve.

A teljesitöképesség elve. A mozgásfejlesztés, mozgástanulás sikerességének hátterében az organi-kus fejlődés áll. A mozgástanulásnál figyelembe kell venni az érést, az életkori sajátosságokat, illetve az ettől való eltéréseket, ami az egyéni sajátosságok figyelembevételét is magában foglalja.

A szilardság elve. Az ismeretek elsajátítása csak akkor sikeres, ha tartósságot bizonyos konstanciát is eredményez. A tartós bevésés az ismeretek meg- 
szilárdítása és a tanultak alkalmazása jelenti. A mozgástanuásban ez a szilárdság azt is jelenti, hogy képes a mozgásokat többször reprodukálni, azonos módon bemutatni, vagy hasonló teljesítményt nyújtani. A célbadobásnál akár valaki véletlenül is eltalálhatja a célfelületet, de amennyiben többszöri végrehajtást kérünk, úgy a „profit” azaz a gyakorlottat az különbözteti meg a véletlen sikertől, hogy többször is képes jó eredménnyel reprodukálni azt (Müller 2004).

A személyre szabottság azért fontos, hogy az egyéni fejlesztés során a lemaradásokat, a hátrányokat lehessen „orvosolni” azokat a mozgásfeladatokat gyakorolni, amelyek elmaradnak az életkori elvárásoktól. A fogyatékosság jellege is meghatározza az egyéni igények figyelembe vételét, hiszen nem mindegy, hogy egy autista, egy vak, vagy hallássérült vagy mozgáskorlátozott mozgásfejlesztését valósítjuk meg.

Motiváció a tanuláshoz, gyakorláshoz elengedhetetlenül fontos a pedagógiában, de a gyógypedagógiai mozgásfejlesztésben különösképp. A sajátos nevelési igényú tanulók belső motivációja akkor alakul ki, amikor a tevékenység végrehajtása motiválja, hiszen mozgásélményt, örömet nyújt neki. Amennyiben megtaláljuk az egyéni igényeknek megfelelő mozgásos feladatot, úgy a motiváció fenntartásával a gyakorlás biztosított, hiszen szívesen végzi majd el a feladatokat a gyerek. A család és s szülők szerepe is meghatározó a mozgásos tevékenységekben a példamutatással az értékközvetítő szerepen keresztül a motiváció kialakításában (Herpainé Lakó J. 2018).

$\mathrm{Az}$ aktivitás elve igen fontos a mozgásfejlesztésben, hiszen itt a végrehajtó gyereknek az aktív, cselekvő közreműködése kell ahhoz, hogy a mozgásfeladatokat végrehajtsa megfelelő elemszámmal, technikai kivitelezéssel, intenzitással.

Közös munka és egyéni bánásmód elve. Ennek az alapelvnek az érvényesülése az integrált és szegregált oktatás egyaránt megjelenik. A fogyatékossággal élő személyek kirekesztettsége ismert, azonban a sport segítheti a társadalmi beilleszkedést és inklúziót egyaránt. A közös mozgás pozitívan hat a szocializációra, a társas kapcsolatokra, melyet a mozgás, mint közösségi élmény megélése biztosít.

A mozgások tanításában és oktatásában ezen alapelveken túl a tanár-tanuló vagy pedagógus és tanár közti interakció fontosságát hangsúlyozza Bíró (2003, 2015), amelynek szerepe nem csak az ismeretátadásában, de a motiválásban és a megfelelő pedagógiai elvek alkalmazásában egyaránt megjelenik.

\section{Összefoglalás}

A mozgásfejlődésnek és a korai életkori szakaszban történő mozgásfejlesztésnek igen meghatározó szerepe van a gyerekek motoros funkcióinak és motoros képességeinek alakulásában, mely egyben a kognitív képességek alakulását is determinálja. A mozgásfejlesztésben a módszertani sajátosságok és elvek figyelembe vételével és azok személyre szabott alkalmazásával lehetôség nyílik a gyerekek mozgásfejlődésbeli elmaradásainak csökkentésére és a hátrányok részbeni leküzdésére. Az ép és a sajátos nevelési igényű gyermekek és felnőttek számára is nélkülözhetetlen a különböző mozgásingerek biztosítása, melyek hozzájárulnak a testi képességek fejlesztéséhez, az állapotjavításhoz, az életminőség javításához vagy akár a szocializációhoz is. A gyógypedagógiai területen dolgozó szakemberek iránt növekvő kereslet van, amit a megnövekedett ellátásra szoruló gyermekek aránya is indukál. A mozgásfejlesztéssel foglalkozó szakembereknek, gyógypedagógusoknak ismerniük kell azokat az alapeleveket, melyek betartásával a sajátos nevelési igényekhez igazodó pedagógiai tevékenységgel a fejlesztési hatékonyság növelhetó.

Jelen tanulmányban - a teljesség igénye nélkül -, a gyógypedagógiai mozgásfejlesztésben megfontolásra érdemes alapelvek és módszertani aspektusok jelentek meg, azonban a téma további feldolgozása elengedhetetlen. 


\section{Irodalom}

Ayres, A.J. (1995). A szenzoros integráció és a gyermek. In Szvatkó A., Varga I. (szerk.): Szenzoros integrációs terápiák. Budapest.

Bartzokis, G., Lu, P. H., Tingus, K., Mendez, M. F., Richard, A., Peters, D. G., Mintz, J. (2010). Lifespan trajectory of myelin integrity and maximum motor speed. Neurobiol Aging, 31(9), 1554-1562.

doi:10.1016/i.neurobiolaging.2008.08.015

Bíró, M (2015). A testnevelés aktuális kérdései. In Révész, László; Csányi, Tamás (szerk.). Tudományos alapok a testnevelés tanitásához. I. kötet: szemelvények a testnevelés, a testmozgás és az iskolai sport tárgyköréböl. Társadalom-, természet- és orvostudományi nérópontok. Budapest, Magyarország: Magyar Diáksport Szövetség. 105-136.

Bíró, M. (2003). Student-Teacher Interaction Analysis for the Teaching of Swimming. In Pavel, Ružbarsky PhD (szerk.) Telesná výchova a šport v tretom tisicročc : Elektronický zbormik \& medzinárodnej vedeckej konferencie. Presov, Szlovákia : Presovovká Univerzita v Prešove. 300-305.

Comenius, J. A. (1657). The Great Didactic of Jhon Ames Comenius. Magyar nyelven: Comenius (1992). Didactica Magna. Seneca Kiadó, Budapest.

Czeizel, B. (2009). A koragyermekkori intervenció múltja, jelene és remélt jövője. Gyógypedagógiai Szemle, 37 (2-3), 153-160.

Dévény A. (2007). Dévény Módszer. A mozgásterápia Új Útja. Semmelweis Kiadó. Bp.

Farmosi I. (1999): Mozgásfejlódés. Dialóg Campus Kiadó. Bp.-Pécs. 14-42.

Geréb Gy. (1958): Comen1us Didaktikai Alapelvei (A nemzetközi Comenius-év tiszteletére). A Szegedi Pedagógiai Föiskola évkönyve 1. 31-53.

Gesell, A. (1933). Maturation and the patterning of behavior. In C. Murchison (Ed.). The International University series in psychology. $A$ bandbook of child psychology (209-235). New York, NY: Russell \& Russell/Atheneum Publishers.

Gortka-Rákó, E. (2017). Családsegítési feladatok új szervezeti formában. In Vargáné, Nagy Anikó (szerk.) Családi nevelés 2. Debrecen, Didakt Kft. 90-101.

Gortka-Rákó, E. (2018): Szociálpedagógiai kompetenciák a koragyermekkori nevelést, gondozást nyújtó intézményekben. Szociálpedagógia $12.15-$ 26.

Guralnick, M. J. (2001). A Developmental Systems' Model for Early Intervention. An Infant and Young Children, Vol. 14/2.

Gyapay, József (1963). A mozgástanulás feltételei és lehetôségei az általános iskola alsó tagozatában. Módszertani közlemények, (3) 1.15-23.

Herpainé Lakó, J. (2018). Three generation research concerning sport and value. In Jaromír, Šimonek; Beáta, Dobay (szerk.) Sport science in motion : proceedings from the scientific conference. Športová veda v pobybe: recenzovaný zbornik vedeckých a odborných prác z konferencie. Mozgásban a sporttudomány: válogatott tanulmányok a konferenciárol. Komárno, Szlovákia : Univerzita J. Selyeho. 274-280.

Katona, F. (2007). Klinikai fejlódésneurológia. Medicina, Budapest.

Kelemen Lajos, Mező Katalin, Mező Ferenc, Szilágyi Barnabás (2015). A korai fejlesztés szemlélete és hazai gyakorlata. In Szilágyi B., Mező K., Mező F.(Szerk.). Az. együttnevelés útjai. Debreceni Egyetem, Debrecen.

Király Zs., Szakály T. (2011): "Mozgásfejlődés és a motorikus képességek fejlesztése gyermekkorban." Dialóg Campus Kiadó.

Kozulin, A., Gindis, B., Ageyev, V. S., \& Miller, S. M. (Eds.) (2003). Vygotsky's educational theory in cul-tural context. Cambridge, United Kingdom: Camb-ridge University Press.

Lábán, R. (1926). Gymnastik und Tan₹. Gerhard Stalling, Oldenburg. 
Lakatos, K. (2000). Korai egyéni és kiscsoportos fejlesztés 1992-1999 között. Fejlesztô" pedagógia, 11. 4-5. 101-118.

Lívják, E., Szabó, B. (2017): A mozgásfejlesztés története Magyarországon. Az Eszterházy Károly Egyetem tudományos közleményei (Új sorozat 44. köt.). Vizsgálatok a sporttudomány és a társadalomtudomány területen. Acta Academiae Agriensis. Sectio Sport, 3-13.

Locke, J. (1801). The Works of John Locke, Johnson.

Maléth A. (2018). Az intellektuális képességzavarral élő személyek társadalmi inklúziója gondolatok és javaslatok a cselekvóképesség korlátozását érintő hazai szabályokról. Családi Jog, (16)1, 9-17

Márkus E. (2017). Halmozott fogyatékosság és testkulturális nevelés. In Benczúr, Miklósné (szerk.) Adaptált testleultúra és sport fogyatékosságspecifizus alapismeretei, ELTE Bárczi Gusztáv Gyógypedagógiai Kar. 193-212.

Márkus E. (2019). Korai fejlesztő és speciális pedagógiai módszerek életkori és fogyatékosságspecifikus bontásban. In Vekerdy-Nagy, Zsuzsanna (szerk.). A gyermekerebabilitáció sajátosságai. Medicina Könyvkiadó Zrt. 243-264.

Marton-Dévényi, É., Szerdahelyi, M., Tóth, G., Keresztesi, K. (1997). Alapozó Terápia. Fejlesztő" Pedagógia. Különszám. 80-107.

McGraw, M. B. (1935/1975). Growth: A study of Johnny and Jimmy. New York: Arno. (Original work published 1935).

McGraw, M. B. (1943). The neuromuscular maturation of the human infant. New York, NY: Columbia University Press.

Mezö, F. (2017). Fejlesztópedagógia elmélet és gyakorlati példatár a képességfejlesztés körében. Kocka Kör, Debrecen.

Mező, K. (2021). Tehetségigéretete azonositása és fejlesztése az óvodában. In Benda, Luca (Szerk.) (szerk.) Egyéni fejlesztés, személyre szabott nevelés. Budapest, Magyarország: Raabe Klett Kiadó. 1-27.
Müller, A. (2004). Mozgásvizsgálatok. A Mozgásegyenletesség és a Teljesítménykonstancia Példá-ján. Doktori disszertáció, Budapest, Semmelweis Egyetem.

Nádori L., Büchler R. (1979). Sportmozgások tanulása. A sport és testnevelés időszerű kérdései. Sport. Budapest, 38.

Oroszné Kosik G. (2005). A mozgásnevelésben alkalmazott terápiák és módszerek. intézményünkben. In Kajáry Ildikó szerk.: Tanulmányok az értelmileg sérïlt gyermekek nevelése és oktatása témakörébõl. Timp Kft., Budapest. 75-89.

Ozsváth K. (1990). Az alsó tagozatos tanulók képességfejlesztésének eredményei hároméves kísérleti program alkalmazásával. MTE közleményei. 1990. 2. sz., 85-121.

Pető, I. (2012). A szenzoros feldolgozás zavara: $A$ z érzékelés szerepe a tanulásba és a viselkedésben. Szeged, Belvedere Meridionale.

Piaget, J. (1976). Piaget's theory. In B. Inhelder, H. H. Chipman, C. Zwingmann (Eds.), Piaget and his school (pp. 11-23). New York, NY: Springer

Roberton, M. A. (1984). Changing motor patterns across childhood. In J. R. Thomas (Ed.), Motor development during childhood and adolescence (pp. 4890). Minneapolis: Burgess.

Rosengren, K. S., Savelsbergh, G. J., \& van der Kamp, J. (2003). Development and learning: a TASC-based perspective of the acquisition of perceptual-motor behaviors. Infant Behavior and Development, 26(4), 473-494.

Stebbins, G. (1913). Delsarte system of dramatic expression. New York E.S Werner

Thelen, E., Schöner, G., Scheier, C., \& Smith, L. B. (2001). The dynamics of embodiment: A field theory of infant perseverative reaching. Behavioral and brain sciences, 24(1), 1-34

Völgyesi, P. (1993). Életkorok pszichológiája. GATE jegyzet, Gödöllő. 13-31. 